\title{
Cash Flow Lending - What A Difference A Year Makes! (Banking Lessons For 2001 And Beyond)
}

Ceil Pillsbury, (Email: ceil@uwm.edu), University of Wisconsin-Milwaukee Roger Pillsbury, (Email: roger.pillsbury@abnamro.com), LaSalle National Bank, Milwaukee, WI

\begin{abstract}
This paper examines the cash flow lending practices that became prevalent in the marketplace during the late 1990s and early 2000. That time frame witnessed bankers significantly deviating from historical lending models which resulted in a marked increase in risk. The detrimental effects of those practices and the repercussions experienced by banks are examined in detail. The paper concludes with suggested modifications to cash flow lending practices and lessons for cash flow lenders.
\end{abstract}

\section{Introduction}

Y t doesn't take a very long memory (even for a banker) to remember 12 months ago when banks were lending up to four and one-quarter times multiple of Adjusted Earnings Before Interest, Taxes, Depreciation and Amortization (EBITDA). That is, if a company had $\$ 10,000,000$ in Adjusted EBITDA, banks would blindly finance $\$ 42,500,000$ in connection with a recapitalization, equity buyout, or merger/acquisition. For the sake of this paper, we will define the "cash flow" of a company as Adjusted EBITDA ${ }^{i}$ and cash flow lending as banks' attempts to predict and understand the cash flow of an enterprise. This paper examines the effects and repercussions of cash flow lending practices and provides guidance about, and lessons for, more realistic future lending practices.

To regress briefly, the traditional bank lending model would examine the balance sheet of a company, "margin" the company's assets, and then lend off those assets. A common example of such traditional lending follows in Table 1.

Under this traditional model, bankers would have made available $\$ 13,868,000$ to $\mathrm{ABC}$ Company in connection with a recapitalization, equity buyout, or merger/acquisition. A common misperception in the marketplace is that banks make significant profits on such loans. In fact, commercial lending has traditionally had relatively narrow margins and a large volume of good loans must be booked to cover even one bad loan. ii Traditionally, more risk, and commensurately more reward, has been the role of mezzanine and equity players.

Readers with comments or questions are encouraged to contact the authors via email. 
Table 1

ABC Company

\section{Account}

Cash

Accounts Receivable

Inventory

Prepaid Expenses

Other Current Assets

Total Current Assets

Property, Plant \& Equipment:

Equipment (OLV*)

Plant \& Property (FMV**)

Other Assets-Goodwill

Total Long Term Assets

Total Assets

*Orderly Liquidation Value

**Fair Market Value (000's omitted)

$\$ 300$

7,027

8,991

606

261

$\$ 17,185$

$\$ 2,344$

2,344

$\underline{2,318}$

$\$ 7,006$

$\$ \underline{24,121}$
Collateral Value @ Margin

x $80 \%=\$ 5,622$

x $50 \%=4,496$

x $80 \%=1,875$

$\mathrm{x} 80 \%=1,875$

$\$ 13,868$

But the mid-to-late 1990's and early into 2000 saw a change in the nature of commercial lending. The Federal Reserve Board reported stiff competition for commercial loans in the mid 1990's with banks easing terms and accepting narrow yield spreads to gain market share [FRB 1997]. This left commercial lending divisions thirsty for profits and by 1998 a loosening of credit standards was reported to the Fed by Senior Loan Officers [FRB May 1998]. About this time an attitudinal change occurred among bankers and the time tested marginal assets approach to banking became too "mechanical" and was actually considered "old fashioned". The new, and quite frankly sexy, part of banking was cash flow lending. With the economy rolling along in a "Goldie Locks" fiii fashion, banks literally took their eyes off the valuation of assets and spent more time lending on what was thought to be an "understandable" and "predictable" cash flow.

Banks invested heavily in cash flow lending divisions by taking many of their youngest, brightest, best-educated, and most open-minded bankers (if there is such a thing) and asking them to lead cash flow lending divisions. Because these divisions were given "a license" to lend beyond the balance sheet it became "the" place to work within the bank. Promising bankers were anxious to get into cash flow lending. Cash flow bankers were interacting daily with investment bankers and venture capitalists who were truly the "money changers" of the 1990's. These individuals either had the money or they knew where to get it. Cash flow lenders quickly became entranced with the "go-go" lifestyles of investment bankers and venture capitalists and their world where deals were plentiful and large sums of money were flowing. Many bankers were secretly dreaming that their new networks would allow them to someday easily transition from the traditional world of commercial banking to the land of exciting lifestyles and mega bonuses. Both banks and bankers became more and more enthralled with the asset generation, pricing, fees and the billions of dollars that venture capitalists were able to raise [Fox 2001; Sullivan and Tally 2001].

With growing assets and increasing profits, banks were blinded to the reality of what cash flow lending really meant. Many bankers thought the venture capitalist money would be the first money lost if cash flow (EBITDA) became less predictable in the future. They believed that the venture capital monies were at risk, not bank funds if the economy were ever to soften. Other bankers thought that protection was afforded by associating with reputable equity players who would take actions (e.g. provide additional equity or halt dividend/interest payments) to protect shaky investments. Neither banks nor bankers 
anticipated what would happen when the Goldie Locks economy inevitably cooled.

\section{Example of Cash Flow Lending of the 1990's}

Let us examine the typical scenario of a cash flow deal in the late 1990's and early in the year 2000. In those rosier days, sellers of companies were commanding multiples in excess of 8 times Adjusted EBITDA and banks were lending at multiples of up to 4.25 Adjusted EBITDA [Sikora 2001]. For the $\mathrm{ABC}$ Company introduced above, we will assume the following:

- Sales $^{\text {iv }} \$ 55,700,000$ with growth rate of $\$ 12.0 \%$ annually for the past 3 years.

- Adjusted EBITDA $\$ 4,729,000$ with growth rate of $16.5 \%$ annually for the past 3 years

Please note - EBITDA is growing faster than sales - Bankers like that!

1. Assume a value of the company of 8.5 times Adjusted EBITDA.

Thus, $8.5 \times \$ 4,729,000=\$ 40,197,000$

$\$ 40,197,000$ is the purchase price of ABC Company.

2. In late 1998,1999 , and early 2000 banks would blindly lend 4 times Adjusted EBITDA. $\$ 4,729,000 \times 4=\$ 18,916,000$.

3. Subordinated debt lenders would lend an additional amount up to 5.25 times EBITDA (in this case another 1.25 of EBITDA)

$\$ 4,729,000 \times 1.25=\$ 5,911,000$

$\begin{array}{lll}\text { 4. Therefore, } & \text { Purchase Price: } & \$ 40,197,000 \\ & \text { Senior Lend: } & (18,916,000) \\ & \text { Subordinated Debt Lenders: } & \frac{(5,911,000)}{\$ 15,370,000}\end{array}$

Purchase price that would have to be made up through seller notes and/or equity.

In addition to lending on high multiples of EBITDA, bankers were also accepting adjustments or "add-backs" to future EBITDA including A) "excessive" owner(s) compensation that was to be eliminated with the recap, buyout or merger/acquisition; B) cost savings that were expected to be realized with new management; $C$ ) synergies associated with mergers and acquisitions that would be gained by the combination of two enterprises D) "non-recurring" expenses that would not happen again under new management--such as receivables charge-offs, additional reserves for inventory obsolescence, additional "one-time" health and dental benefits where rates would decrease in future years, work stoppages that incurred in the past etc., etc., etc.

The difference of the $\$ 18,916,000$ that banks were willing to lend in the late 1990 's and the $\$ 13,868,000$ that banks would have lent on the company under the traditional collateralized lending approach is the increase risk that banks exposed themselves to when they began lending on the "cash flow" of a company. Thus, banks would be putting approximately $\$ 5,000,000$ more at risk for a company that they wouldn't even think about doing that for a few years earlier. Sure, banks were growing in assets and generating more fee income by lending on the cash flows of companies, but banks were certainly not being compensated nearly enough through increased interest or fees for the commensurate amount of risk they were assuming. Nor were banks taking the additional steps necessary to monitor these riskier credits 
in a prudent and profitable manner. This would become apparent to banks, but not until after the economic softening in Spring of 2000.

In fact, the problems with cash flow lending were apparent to the Office of the Comptroller of the Currency (OCC) and Federal Reserve Board long before banks acknowledged the problems [FRB 1998 and 1999; OCC 1999]. Despite warnings from regulators, banks were slow to tighten underwriting standards.

Banks began to recognize in the second quarter of 2000 what became clearly apparent in the third and fourth quarter: highly leveraged companies have diminished abilities to respond to negatively changing economic conditions and, consequently, are therefore a much greater credit risk than companies in a stronger financial position. By late 2000 the issues with highly leveraged cash flow lending became critically apparent to banks as these companies were no longer able to execute on projected efficiencies post recapitalization/buyout/acquisition. The more the economy softened, the greater the difficulty companies had in meeting projected EBITDA, much less Adjusted EBITDA numbers. Banks began to realize loan losses as the overly optimistic assumption about cash flows failed to materialize. It was painfully discovered that the once thought to be "understandable" and "predictable" cash flows were not so understandable and predictable after all. The predictability became less predictable as the "expected" add-backs were not realized and the "Goldie Locks" economy became "not so hot, but actually cold," By mid 2000 Senior Loan Officers reported to the Fed that they were becoming significantly more cautious in their lending practices but by then, of course, the damage had already occurred [FRB 2000].

As the problems materialized, aggregate commercial bank industry earnings fell during the year 2000 for the first time in ten years [Greenspan and Hawke, 2001].

Write-offs and loan loss provisions started increasing in response to the deteriorating asset quality. Below is a sampling of quarterly loan loss provisions (000's omitted):

\begin{tabular}{lrrrrr} 
& $\underline{\mathbf{0 3 / 3 1 / 0 0}}$ & $\underline{\mathbf{0 6 / 3 0 / 0 0}}$ & $\underline{\mathbf{0 9 / 3 0 / 0 0}}$ & $\underline{\mathbf{1 2 / 3 1 / 0 0}}$ & $\underline{\underline{\mathbf{0 3 / 3 1 / 0 1}}}$ \\
\cline { 2 - 3 } & 420,000 & 470,000 & 435,000 & $1,210,000$ & 835,000 \\
Finova Group Inc. & 98,000 & 39,800 & 111,237 & 393,693 & 61,750 \\
Bank One Corp. & 362,000 & $1,013,000$ & 516,000 & $1,507,000$ & 585,000 \\
Marshall \& Ilsley & 5,819 & 9,616 & 5,938 & 8,979 & 11,063
\end{tabular}

Sources: Edgar Online

Finova Group Inc. ${ }^{\text {vi }}$ filed bankruptcy in May 2001.

As noted by John D. Hawke Jr, Comptroller of the Currency, the ratio of loan loss reserves to loans had eroded to approximately $1.5 \%$ by 2001 and he expected future bank earning to be impacted by the need to further bolster loan loss allowances [Greenspan and Hawke 2001].

\section{Lending Later in the Year 2000}

By the late summer of 2000, senior bank lenders were no longer lending 4.25 on Adjusted EBITDA, but 3.50 times on Unadjusted EBITDA with higher pricing and more fees. By the end of the year 2000 , banks that were still in the cash flow lending business were down to multiples of $2.75 / 3$ times senior debt to EBITDA [Morse and Palmer 2001]. Pricing on these loans became "prime based" or Libor "plus 350 basis points (bpts) for the secured portion of the transaction and 400 bpts for the unsecured loan. Fees were a minimum of $1.50-2.0 \%$ of the total commitments. As the senior bank debt multiples decreased 
companies looked to the next cheapest source of funding to fill the gap. Mezzanine and/or subordinated debt players began to fill the void between 3 times EBITDA and the 4.25 that was once occupied by senior lenders. Needless to say, the mezzanine players, were delighted to reduce their risk by lending on a lower multiples of cash flow, yet still earning their desired "all-in" $18 \%-22 \%$ return.

We will assume for the sake of argument the same sales, EBITDA, and balance sheet numbers of fictitious Company $\mathrm{ABC}$, the following is how banks in the second half of 2000 were underwriting cash flow transactions.

1. Value of the company 8.5 times EBITDA.

Thus, $8.5 \times \$ 4,729,000=\$ 40,196,000$

$\$ 40,196,000$ is the purchase price of $A B C$ Company.

2. By late 2000 banks would only lend approximately 3.00 times Unadjusted EBITDA.

That is, 3.25 times $\$ 4,729,000=\$ 15,369,250$.

3. $\$ 4,729,000 \times 4.0=\$ 18,916,000$

Subordinated debt lenders would lend up to 4.0 times EBITDA.

4. $\$ 18,916,000$

$15,369,250$

$\$ 3,546,750$

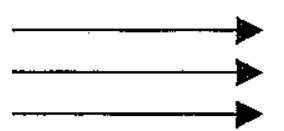

Subordinated debt at 4.0 times EBITDA Senior

Senior Lending at 3.25 times EBITDA purchase

Amount of subordinated debt that ABC Company could borrow.

5. Therefore,

Purchase Price:

$\$ 40,196,000$

Senior Lend:

$\$ 15,369,250$

Subordinated Debt Lenders: $\quad \$ 3,546,750$

$\$ 21,280,000$

Purchase price that would have to be made up through seller notes and/or equity.

The example shown above does not take into affect the "double whammy" of lower EBITDA's and lower multiples, since we are assuming the same EBITDA's for comparison purposes.

\section{Cash Flow Lending in the Year 2001 and Beyond}

Softness reflected in earnings continued beyond the second half of 2000 into 2001. As a result, banks are now revisiting the "age old" margined asset approach to banks. Yes, even in "cash flow" deals, and even where there are investment banks and venture capitalist monies.

We believe cash flow lending presently and in the future will be a combination of traditional financing off of the balance sheet AND a close examination of a company's cash flow. That is, banks will lend the $\$ 13,867,000$ on margined assets AND will lend up to 2 years undersecured ${ }^{\text {vii }}$ based upon the cash flow of the company. Banks will understand their margined asset position and then lend additional money. Banks will lend additional money for the recaps/buyouts/acquisitions but will not want to be "out of margin" for over two years. Banks will feel the need to be back in a margined position within the 18-24 months of making the original lend. In our example of $\mathrm{ABC}$ Company, the cash flow was $\$ 4,729,000$ assuming:

- A line of credit is established for the working capital needs of the company for $\$ 13,000,000$. 
Initial Draw is $\$ 10,000,000$ for the acquisition. No principal payments on the line are required, only interest at $8 \%$.

- Principal required on the plant, property and equipment loan is paid over 10 years (straight line).

Cash Flow of ABC Company

- Interest on Line of Credit

$\$ 10,000,000 @ 8 \%=$

$\$ 7,500,000 \div 10$ year

$\$ 7,125,000 @ 8.5 \%$

- Interest on Term Financing On Average OutstandingFor First Year

- Maintenance Capital Expenditures

- Taxes at $40 \%$ Rate
$\$ 3,323,375 @ 40 \%=$

$$
\$ 4,729,000
$$

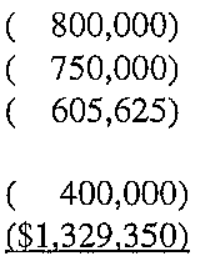

$(\$ 3,884,975)$

$\$ 844,024^{\mathrm{ix}}$

Net Cash Flow of ABC Company

A bank may be willing to lend beyond the $\$ 13,867,000$ in margined assets an additional $\$ 844,000$ because that is the "free cash flow" of the company. Therefore, assuming the same sales price multiple of 8.5 times, in the year 2001. A bank would lend $\$ 13,867,000$, plus one or two years of free cash flow. That is an additional $\$ 844,000$ or for two years $\$ 1,688,000$.

\section{$\$ 13,867,000$ \\ 844,000 One year "free cash flow" \\ $\$ 14,711,000$ Banks willing to lend in Year 2001
$\$ 13,867,000$
$1,688,000$ Two years of "free cash flow"
$\$ 15,555,000$ Banks willing to lend in Year 2001

In summary:

- Banks traditionally lent on margined assets

$\$ 13,867,000$

- Banks were lending in late 1990's (4 times cash flow)

$\$ 18,916,000$

- Banks lending in the Year 2001 and beyond

$\$ 14,711,000-\$ 15,555,000$

\section{Lessons To Be Learned for 2001 and Beyond}

1. Know your collateral. The historically prudent and profitable method of commercial lending involves understanding a company's assets. This method has been tried and true through all economic cycles and there is a reason WHY is has been the traditional model. While margining assets may not be very thrilling, it provides a reasonable return for the amount of risk assumed.

2. Be happy with what you are. Commercial bankers aren't investment bankers or venture capitalist and they shouldn't try to be. Commercial banking serves a critical function in the capital market by providing companies with access to funds at a reasonable cost and bankers need to value this role, not seek to fill the roles of others.

3. Don't make equity investments at loan spreads. Banks simply do not make enough spread over interest to accept the equity risks. Banks are in a low margin business and an industry simply cannot 
afford to accept higher risks in low margin businesses.

4. Don't believe in "add-backs." Lend only on historical cash flow, not what might happen. Adopt a "show me the money" attitude on every loan and make a realistic assessment of each borrower's prospects.

5. Cash flow is inherently unpredictable. Thinking that bankers or anyone can understand the real cash flow of a business is a VERY difficult proposition.

6. The "Goldie Locks" economy was a fairy tale. We don't believe in fairy tales in real life, so we certainly should not when REAL dollars are involved! When good economic times are here they should be enjoyed, but not at the expense of sound underwriting practices.

\section{Endnotes}

1. Adjusted EBITDA is EBITDA adjusted for "add-backs" which are discussed later in the paper.

2. Assume an interest margin of $3.5 \%$ on a $\$ 5,000,000$ loan resulting in net interest margin or $\$ 175,000$. To cover the charge--off associated with one bad loan of $\$ 5,000,000$ you must have approximately 29 good loans $(\$ 5,000,000 / \$ 175,000)$. Thus, profitable commercial lending divisions must typically produce large loan volumes and minimize loan charge-offs. Kovacevich[2001] notes that banks must make good loans $99.5 \%$ of the time to earn a reasonable profit.

3. "Goldie Locks economy" was a common nickname of the economy in the United States in the (late???) 1990's. The economy was "not too hot and not too cold", thus the reference to Goldie Locks and her adventure with the three bears.

4. Banks usually required sales greater than $\$ 20,000,000$ for cash flow candidates. Companies with less than $\$ 20,000,000$ in sales were not considered because of the belief that a sufficiently developed infrastructure would not exist for the company to have significant value absent the entrepreneur.

5. Again, a minimum EBITDA of $\$ 2,000,000$ was required because this inferred sustainability, and value of the enterprise.

6. On May 2, 2001, Finova Group Inc. and eight of its subsidiaries filed a Joint Plan of Reorganization with the United States Bankruptcy Court for the District of Delaware. (C) 2001 PR Newswire

7. Libor-London Interbank Offering Rate.

8. Undersecured means that the bank will still take a general business security interest in all of $A B C$ Company assets, but be "out of margin" for a period of time.

9. This assumes no working capital changes.

\section{References}

1. Federal Reserve Board, "Senior Loan Officer Opinion Survey on Bank Lending Practices", January 1997, Page 1.

2. Federal Reserve Board, "Senior Loan Officer Opinion Survey on Bank Lending Practices", May 1998, Page 1.

3. Federal Reserve Board, Supervisory Letter, SR 98-18, 1998.

4. Federal Reserve Board, Supervisory Letter, SR 99-23, 1999.

5. Federal Reserve Board, "Senior Loan Officer Opinion Survey on Bank Lending Practices", May 2000, Page 1.

6. Fox, Loren, "Venture Capital is Not Dead", http://www.business2.com/ebusiness/2001/02/26267.htm.

7. Greenspan, Alan, and John D. Hawke Jr., "A Delicate Balance", Risk Management Association Journal, May 2001, pp. 26-33.

8. Kovacevich, Richard M, "Seven Reasons for Unprofitable Lending", Risk Management Association Journal, May 2001, pp. 19-23.

9. Morse, Jeffrey and Colleen Palmer, "Straight Talk", Heller Financial, February, 2001, pp. 1-3.

10. Sikora, Michael, "Uncertainties Cloud the M\&A Outlook in 2001", Mergers \& Acquisitions, 
February 2001, pp. 4-8.

11. Sullivan, John and Greg Tally, "A Venture Capitalist with a View", http://www.ispworld.com/finance/AC_021201.htm.

12. Office of the Comptroller of the Currency, Advisory Letter 99-4, May 1999.

Notes

5 